\title{
DYNAMIC MODELLING OF PISTON THE MOTION IN COMBUSTION ENGINES
}

Sunny Narayan ${ }^{1, *}$, Shitu Abubakar², Muhammad Usman Kaisan², Hauwa Ndagi ${ }^{2}$, Yunusa Tukur ${ }^{3}$, Ivan Grujić ${ }^{4}$, Nadica Stojanović ${ }^{4}$

${ }^{1}$ Mechanical Engineering Department, Qassim University, Burydah, Saudi Arabia

${ }^{2}$ Mechanical Engineering Department, Ahmadu Bello University, Zaria, Nigeria

${ }^{3}$ Department of Energy Planning and Analyses, Energy Commission of Nigeria, Abuja, Nigeria

${ }^{4}$ Department of Motor Vehicles and Motors, University of Kragujevac, Kragujevac, Serbia

*E-mail of corresponding author: rarekv@gmail.com

\section{Resume}

The presented work discusses a methodology for analysis of noise emissions from a diesel engine. A numerical model of the piston motion, analyzing its lateral, reciprocating and rotation motion, has been presented in order to investigate the lateral motion of the piston skirt assembly and resulting vibrations induced as a result of these motions in the engine block. Various parameters of modal analysis were obtained using the mobility analysis. The presented methodology was validated by data obtained from a diesel engine test set up. The predicted results matched well with those of measured data, hence validating the presented scheme.

Available online: https://doi.org/10.26552/com.C.2022.1.B9-B19

\section{Article info}

Received 17 March 2021

Accepted 2 June 2021

Online 30 September 2021

\section{Keywords:}

acoustics, vibrations, noise, piston motion

\section{Introduction}

In combustion engines a lateral space is present between the skirt and a cylinder liner that gives a motion freedom in lateral direction during the engine operation [1]. The existence of this gap puts a limit on magnitude of piston motion [2]. The piston assembly contributes to about $30-40 \%$ of mechanical losses and hence its design is a major concern for automotive engineers [3-4]. The piston thrusts liner to other side due to changing in direction of side thrust force due to motion of a connecting rod [5-6].

A dynamic model of the crank slider mechanism has been presented by Flores et al. [2]. The existence of lateral gap makes the system nonlinear and chaotic in nature. The reaction force between the liner and a skirt also plays an important role in dynamics of motion. As the coefficient of restitution decreases, the motion transforms from bouncing to a periodic one [7-8].

McFadden and Turnbul analyzed effects of combustion gas pressure on primary motion of a piston [9]. A two degree of freedom system has been analyzed showing a correlation between the piston slap and resulting vibrations [10-16]. Various parameters affecting piston motion has been considered, which includes location of a center of gravity [17], profile of a skirt [1819], effects of inertial forces [20-21], frictional forces [22] and lubricating oil [23]. Mounted accelerometers on the block surface were used to simulate the piston's secondary motion [5].

\section{Piston assembly model}

The secondary motion of a skirt for the case of a 240 cc engine was modeled as depicted in Figure 1. The piston was considered as a point mass of $0.363 \mathrm{~kg}$ $\left(\mathrm{m}_{\mathrm{p}}\right)$ and inertia $\left(\mathrm{I}_{\mathrm{p}}\right)$ of $7.8540 \times 10^{-9} \mathrm{~kg}-\mathrm{m}^{2}$ having two degree of freedom in motion $\left(\mathrm{X}_{\mathrm{p}}, \theta\right)$. The cylinder block was considered as a lumped mass of $48.5 \mathrm{~kg}\left(\mathrm{~m}_{\mathrm{b}}\right)$ with a single degree of freedom $\mathrm{X}_{b}$, as shown in equation (1).

The nominal clearance of $0.5 \mathrm{~mm}$ allows the piston assembly to move in the lateral direction, as well as to rotate about the piston pin. The clearance between the skirt and a liner Xc was modeled as a mechanical stop in lateral direction.

For condition of no impact, $\left(\mathrm{X}_{\mathrm{p}}-\mathrm{X}_{\mathrm{b}}=\mathrm{X}_{\mathrm{c}}\right)$ the motion was governed by Equation (1). 


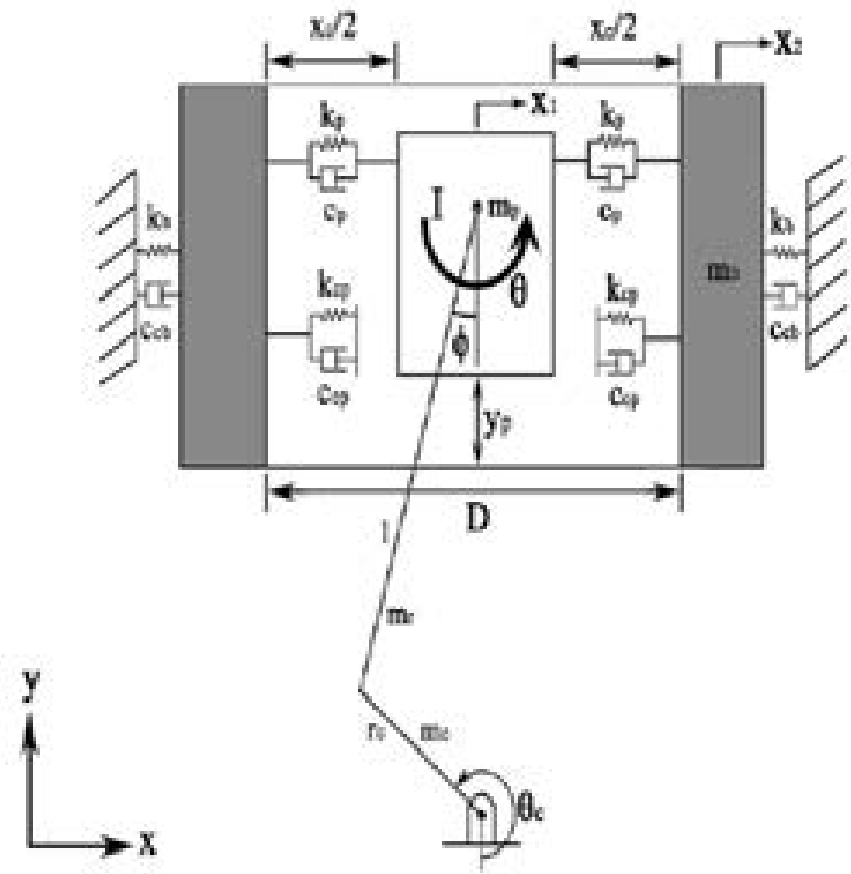

Figure 1 Numerical model of the piston motion

$$
\begin{aligned}
& \left(\begin{array}{ccc}
m_{p} & 0 & 0 \\
0 & m_{b} & 0 \\
0 & 0 & I_{p}
\end{array}\right)\left(\begin{array}{c}
X_{p}^{\prime \prime} \\
X_{b}^{\prime \prime} \\
\theta^{\prime \prime}
\end{array}\right)+\left(\begin{array}{ccc}
C_{p} & -C_{p} & 0 \\
-C_{p} & C_{p}+C_{b} & 0 \\
0 & 0 & C_{\theta}
\end{array}\right)\left(\begin{array}{c}
X_{p}^{\prime} \\
X_{b}^{\prime} \\
\theta^{\prime}
\end{array}\right)+ \\
& \left(\begin{array}{ccc}
k_{p} & -k_{b} & 0 \\
-k_{p} & k_{p}+k_{b} & 0 \\
0 & 0 & k_{\theta}
\end{array}\right)\left(\begin{array}{c}
X_{p} \\
X_{b} \\
\theta
\end{array}\right)=\left(\begin{array}{c}
F_{x} \\
0 \\
M_{z}
\end{array}\right) .
\end{aligned}
$$

\section{Piston side thrust force}

The major issue, affecting this lateral motion of a skirt, is the side thrust force ( $\mathrm{Fx})$ imparted to skirt by a connecting rod, as shown in Figure 2.

The frictional forces act between the piston skirt and a cylinder liner $\left(\mathrm{F}_{\mathrm{f}}\right)$ as well as between the rings and a liner $\left(\mathrm{F}_{\mathrm{fr}}\right)$. The force exerted by the connecting rod on piston pin was resolved along $\mathrm{X}\left(\mathrm{F}_{\mathrm{rodX}}\right)$, as well as $\mathrm{Y}$ axis $\left(\mathrm{F}_{\text {rodY }}\right)$. The side thrust force $\left(\mathrm{F}_{\mathrm{x}}\right)$ takes into consideration both inertial forces as well as gas forces $\left(\mathrm{F}_{\mathrm{g}}\right)$ [21-24].

$\mathrm{F}_{\mathrm{x}}=\left[\mathrm{F}_{\mathrm{g}}-\mathrm{m}_{\mathrm{p}} \mathrm{r} \omega^{2}[\cos (\theta)+\mathrm{K} \cos (2 \theta)]\right] \lambda$,

where: $m_{p}$ - mass of piston,

$\theta$ - crank angle,

$\omega$ - angular speed,

$\mathrm{r}$-crank radius,

$\mathrm{K}$ - crank radius-connecting rod length ratio,

$\left.\lambda=\mathrm{K} \cos (\theta) / \sqrt{ }(1+\sin (\theta)]^{2}\right)$.

\section{Piston frictional force}

Various friction forces play a predominant role in the total mechanical loss of an engine [25-26]. According to Zweiri et al. [27], frictional force between the rings and a liner can be obtained from the product of elastic tension and the coefficient of frictional force. As the speed of engine increases, the coefficient of friction decreases gradually until reaching the minimum at the mid stroke. The frictional forces between the liner and a skirt $\left(\mathrm{F}_{\mathrm{f}}\right)$ and piston rings and liner $\left(\mathrm{F}_{\mathrm{fr}}\right)$ may be expressed in terms of the sliding velocity of a piston $(\mathrm{V})$, nominal clearance (h), lubricating oil viscosity $(\mu)$, number of piston rings (n) and the shear area of a contact $\left(\mathrm{A}_{\mathrm{s}}\right)$ as [27-57]:

$\mathrm{F}_{\mathrm{f}}=\mu \mathrm{VA}_{\mathrm{s} 1} / \mathrm{h}$,

$\mathrm{F}_{\mathrm{fr}}=\mathrm{n} \mu \mathrm{VA}_{\mathrm{s} 2} / \mathrm{h}$

where $A_{s 1}$ is the shear contact area between the liner and a skirt and $\mathrm{A}_{\mathrm{s} 2}$ is the shear contact area between the liner and rings.

\section{Mobility parameter determination}

The mobility may be defined as the ratio of velocity response $V(J \omega)$ of a structure to exciting force $F(J \omega)$ acting on a structure [5]:

$\mathrm{M}(\mathrm{J} \omega)=\mathrm{V}(\mathrm{J} \omega) / \mathrm{F}(\mathrm{J} \omega)$,

$\mathrm{M}(\mathrm{J} \omega)=-\mathrm{J} \omega\left(\left(\mathrm{K}-\mathrm{M} \omega^{2}\right)+\mathrm{JC} \omega\right) / \mathrm{M} \omega^{2}(\mathrm{~K}+\mathrm{JC} \omega)$,

In the frequency range below the first anti resonance frequency value $\left(\omega_{\mathrm{a}}=\mathrm{K} / \mathrm{m}\right)$, the point mobility equation can be approximated as [5, 31-32]:

$\mathrm{M}(\mathrm{J} \omega)=-\mathrm{J} / \mathrm{m} \omega_{\mathrm{a}}$. 


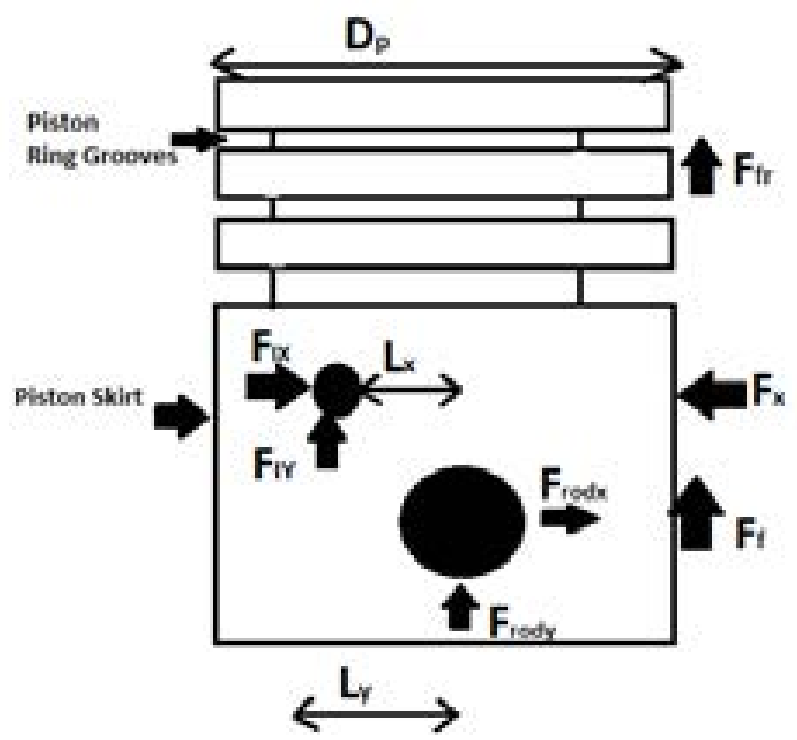

Figure 2 Force diagram of the piston skirt assembly

Above the anti resonance frequency, the point mobility can be written as :

$\mathrm{M}(\mathrm{J} \omega)=-\mathrm{J} \omega_{\mathrm{a}} / \mathrm{K}$

\section{Experimental setup}

Tests were done on a single cylinder HARTZ engine having specifications as presented in Table 1.

The in-cylinder pressure was monitored by an AVL transducer, having specifications shown in Table 2. Block vibrations were measured by means of an Endveco7240C type Mono axial accelerometer, having features accelerometer are presented in Table 3.

Various engine testing speeds in rpm (Revolutions

Table 1 Engine specifications

\begin{tabular}{cc}
\hline Type & Diesel Engine \\
\hline Make & HARTZ \\
Number of cylinders & 1 \\
Bore & $69 \mathrm{~mm}$ \\
Stroke & $65 \mathrm{~mm}$ \\
Displacement & $0.243 \mathrm{liter}$ \\
Compression & $22: 1$ \\
Maximum power & $3.5 \mathrm{~kW} @ 4400 \mathrm{rpm}$ \\
Maximum torque & $10 \mathrm{~N}-\mathrm{m} @ 2000 \mathrm{rpm}$ \\
\hline
\end{tabular}

per minute)-(2000 rpm and $3000 \mathrm{rpm}$ ) and load values (80\% and $100 \%)$ were chosen with an aim to cover complete engine operational conditions. The data recorded during each test was under steady state conditions as seen in Table 4.

Figure 3 shows the general layout of the test rig with placement of various sensors.

\section{Results and discussions}

Figures 4 and 5 depict variations of the piston side thrust force. This force changes its direction five times in a complete engine cycle indicating five possible instances of lateral contact of the skirt with a liner.

COMSOL 7 multi physics software was used to

Table 2 Pressure transducer specifications

\begin{tabular}{cc}
\hline Range & $0-250 \mathrm{Bar}$ \\
\hline Sensitivity & $20 \mathrm{pC} / \mathrm{Bar}$ \\
Resonance Frequency & $160 \mathrm{kHz}$ \\
\hline & \\
Table 3 Accelerometer specifications & \\
\hline Range & $1000 \mathrm{~g}$ \\
Sensitivity & $3 \mathrm{pC} / \mathrm{g}$ \\
Resonance Frequency & $90 \mathrm{kHz}$ \\
\hline
\end{tabular}

Table 4 Testing specifications

\begin{tabular}{cccc}
\hline Case & rpm & Load & P $_{\text {injection }}($ Bar $)$ \\
\hline 1 & 2000 & $80 \%$ & 716 \\
2 & 2000 & $100 \%$ & 692 \\
3 & 3000 & $80 \%$ & 814 \\
4 & 3000 & $100 \%$ & 612 \\
5 & 3000 & - & 512 \\
\hline
\end{tabular}




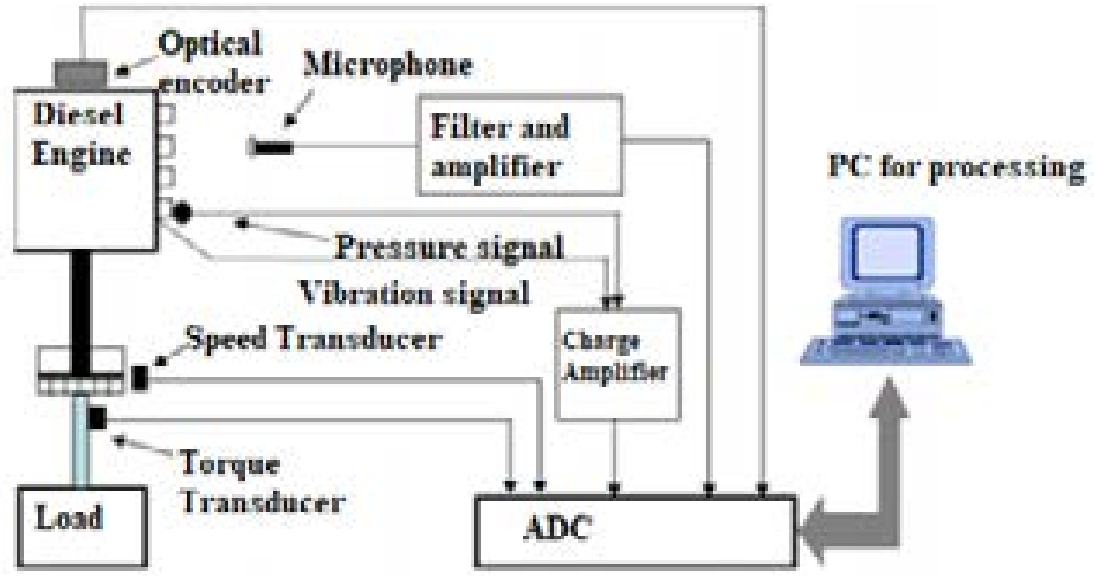

Figure 3 Experimental setup

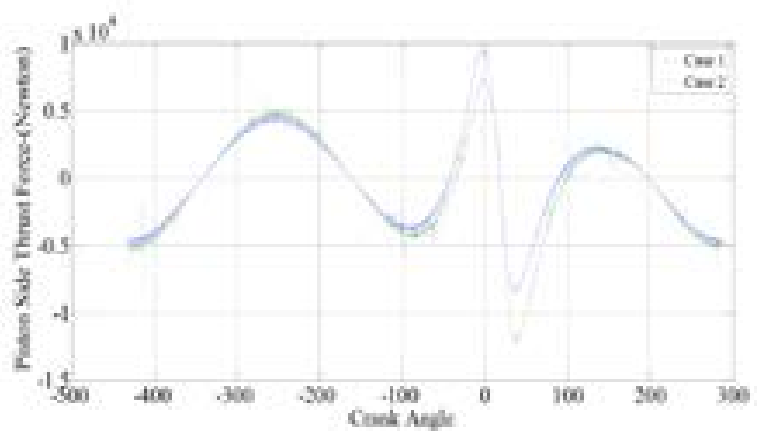

Figure 4 Variations of the piston side thrust force (2000 rpm)

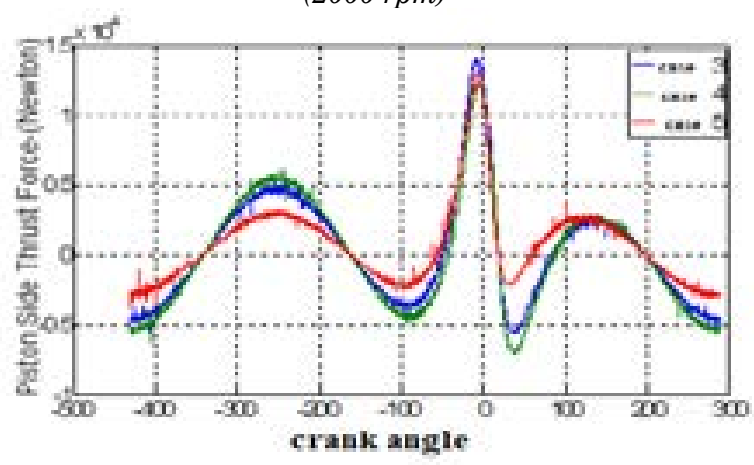

Figure 5 Variations of the piston side thrust force (3000 rpm)

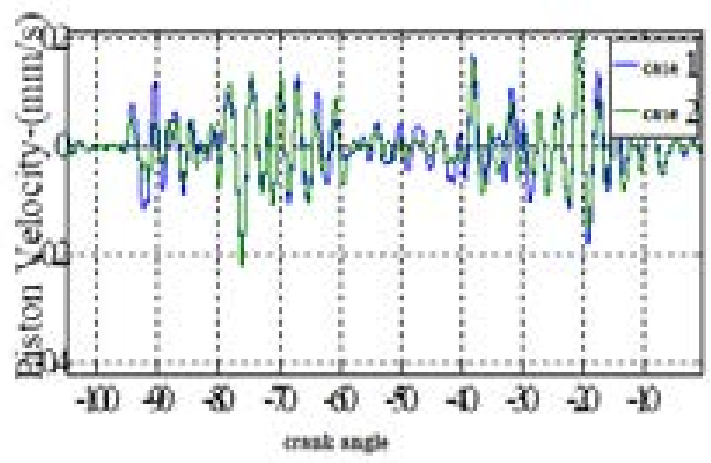

Figure 6 Variations of the piston velocity (2000 rpm)

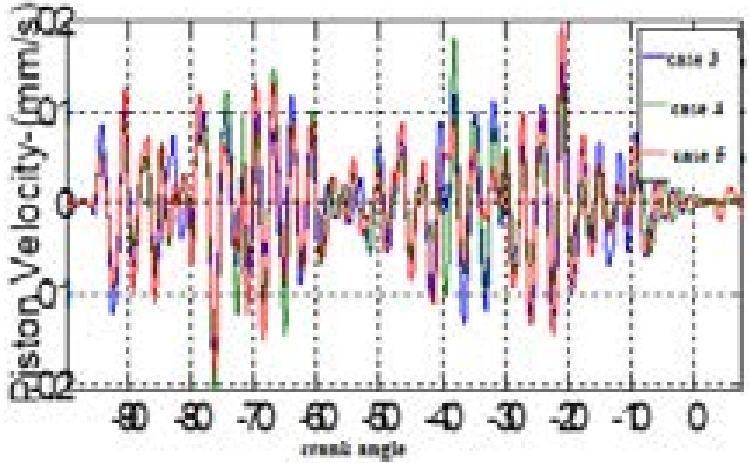

Figure 7 Variations of the piston velocity (3000 rpm)

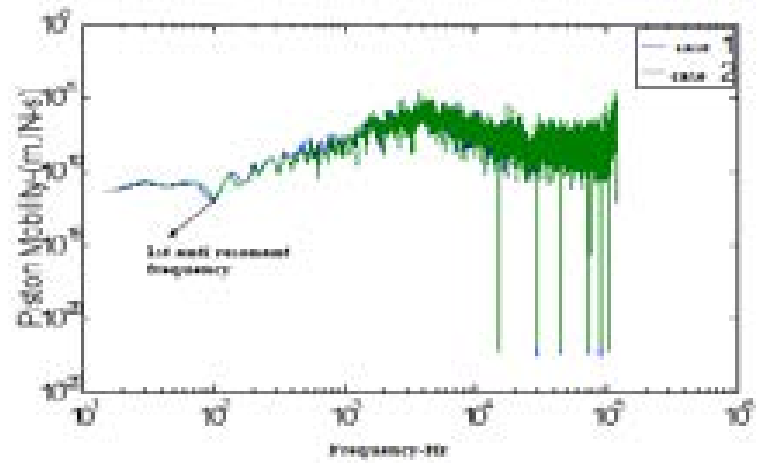

Figure 8 Variations of the piston mobility (2000 rpm)

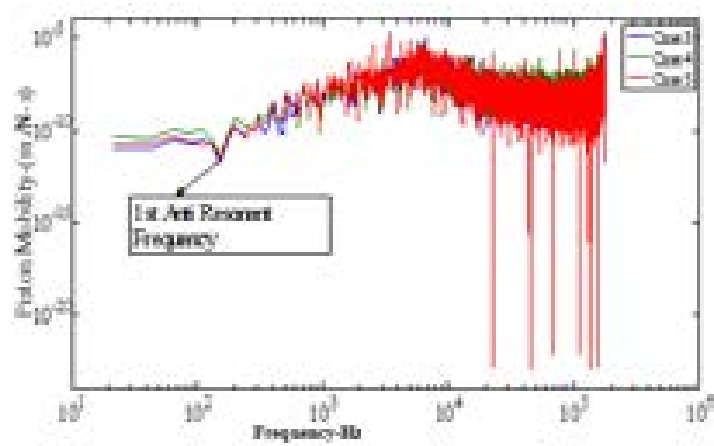

Figure 9 Variations of the piston mobility (3000 rpm) 


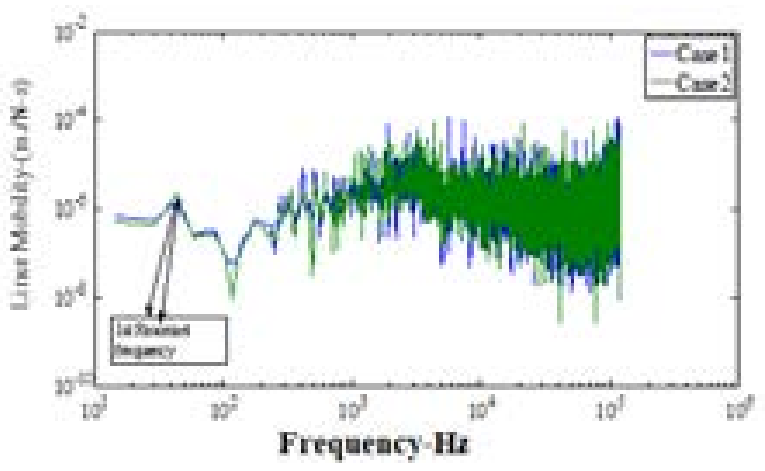

Figure 10 Variations of the piston mobility (2000 rpm)

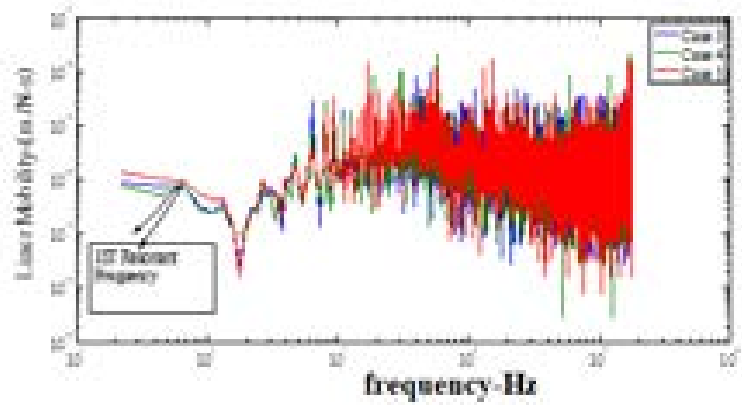

Figure 11 Variations of the piston mobility (3000 rpm)
Table 5 Dynamic features of a system

\begin{tabular}{ccc}
\hline Test case & Piston parameter & Liner parameter \\
\hline \multirow{3}{*}{1} & $\omega_{\mathrm{a}} 100 \mathrm{~Hz}$ & $\omega_{\mathrm{a}} 39 \mathrm{~Hz}$ \\
& $\mathrm{C}_{\mathrm{p}} 109330(\mathrm{~kg} / \mathrm{s})$ & $\mathrm{C}_{\mathrm{b}} 42884(\mathrm{~kg} / \mathrm{s})$ \\
& $\mathrm{K}_{\mathrm{p}} 174\left(\mathrm{~kg} / \mathrm{s}^{2}\right)$ & $\mathrm{K}_{\mathrm{b}} 175\left(\mathrm{~kg} / \mathrm{s}^{2}\right)$ \\
& $\mathrm{m}_{\mathrm{p}} 174(\mathrm{~kg})$ & $\mathrm{m}_{\mathrm{b}} 175(\mathrm{~kg})$ \\
& $\omega_{\mathrm{a}} 100 \mathrm{~Hz}$ & $\omega_{\mathrm{a}} 39 \mathrm{~Hz}$ \\
2 & $\mathrm{C}_{\mathrm{p}} 10930(\mathrm{~kg} / \mathrm{s})$ & $\mathrm{C}_{\mathrm{b}} 109330(\mathrm{~kg} / \mathrm{s})$ \\
& $\mathrm{K}_{\mathrm{p}} 174\left(\mathrm{~kg} / \mathrm{s}^{2}\right)$ & $\mathrm{K}_{\mathrm{b}} 174\left(\mathrm{~kg} / \mathrm{s}^{2}\right)$ \\
& $\mathrm{m}_{\mathrm{p}} 174(\mathrm{~kg})$ & $\mathrm{m}_{\mathrm{b}} 174(\mathrm{~kg})$ \\
& $\omega_{\mathrm{a}} 158 \mathrm{~Hz}$ & $\omega_{\mathrm{a}} 63 \mathrm{~Hz}$ \\
& $\mathrm{C}_{\mathrm{p}} 172750(\mathrm{~kg} / \mathrm{s})$ & $\mathrm{C}_{\mathrm{b}} 69669(\mathrm{~kg} / \mathrm{s})$ \\
& $\mathrm{K}_{\mathrm{p}} 174\left(\mathrm{~kg} / \mathrm{s}^{2}\right)$ & $\mathrm{K}_{\mathrm{b}} 175\left(\mathrm{~kg} / \mathrm{s}^{2}\right)$ \\
& $\mathrm{m}_{\mathrm{p}} 174(\mathrm{~kg})$ & $\mathrm{m}_{\mathrm{b}} 176(\mathrm{~kg})$ \\
& $\omega_{\mathrm{a}} 158 \mathrm{~Hz}$ & $\omega_{\mathrm{a}} 63 \mathrm{~Hz}$ \\
& $\mathrm{C}_{\mathrm{p}} 10930(\mathrm{~kg} / \mathrm{s})$ & $\mathrm{C}_{\mathrm{b}} 109330(\mathrm{~kg} / \mathrm{s})$ \\
& $\mathrm{K}_{\mathrm{p}} 174\left(\mathrm{~kg} / \mathrm{s}^{2}\right)$ & $\mathrm{K}_{\mathrm{b}} 174\left(\mathrm{~kg} / \mathrm{s}^{2}\right)$ \\
& $\mathrm{m}_{\mathrm{p}} 174(\mathrm{~kg})$ & $\mathrm{m}_{\mathrm{b}} 174(\mathrm{~kg})$ \\
& $\omega_{\mathrm{a}} 158 \mathrm{~Hz}$ & $\omega_{\mathrm{a}} 63 \mathrm{~Hz}$ \\
& $\mathrm{C}_{\mathrm{p}} 172750(\mathrm{~kg} / \mathrm{s})$ & $\mathrm{C}_{\mathrm{b}} 69669(\mathrm{~kg} / \mathrm{s})$ \\
& $\mathrm{K}_{\mathrm{p}} 174\left(\mathrm{~kg} / \mathrm{s}^{2}\right)$ & $\mathrm{K}_{\mathrm{b}} 175\left(\mathrm{~kg} / \mathrm{s}^{2}\right)$ \\
& $\mathrm{m}_{\mathrm{p}} 174(\mathrm{~kg})$ & $\mathrm{m}_{\mathrm{b}} 176(\mathrm{~kg})$ \\
& &
\end{tabular}

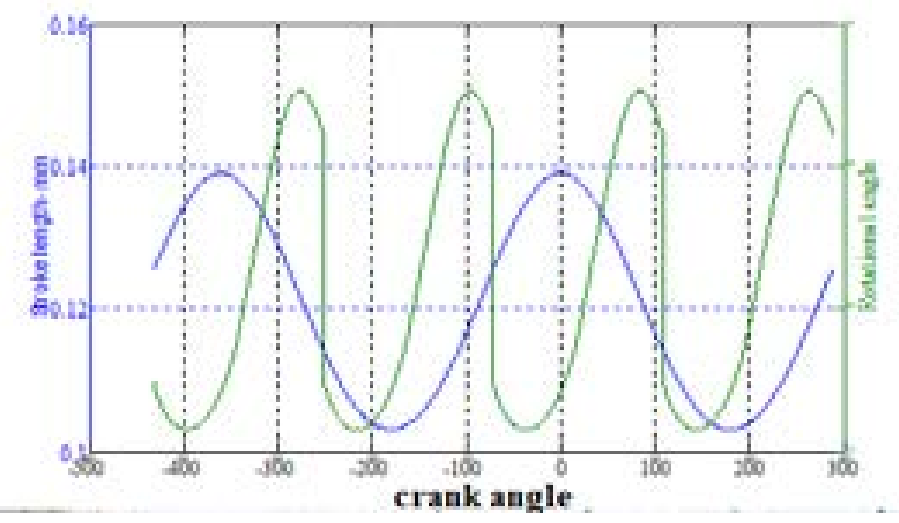

Figure 12 Variations of the rotation motion of a skirt (Case 1)

simulate the piston velocity for given testing conditions, as shown in Figures 6 and 7.

Using Equation (6), the mobility was computed, e as seen in Figures 8 and 9.

Similarly, the Mobility of a $\mathrm{r}$ cylinder block was computed using integration of accelerometer data as shown in Figures 10 and ,11.

Using the concept of anti-resonant frequency $\left(\omega_{\mathrm{a}}\right)$, as discussed in previous section, various dynamic parameters of the liner-piston were computed for the given test conditions (Table 4), as seen in Table 5.

During the motion simulation, the bottom dead center positions (BDC) was taken as a reference point. The initial location of a piston is set at $0 \mathrm{~mm}$ as the bottom boundary of liner and the upper boundary of the cylinder liner is set at $0.5 \mathrm{~mm}$, which is a clearance between the skirt and a liner.

As seen from Figure 12, the piston tilting angle changes its direction at both dead centers. In order to visualize the pistons secondary motion during the reciprocating motion, the piston secondary motion is represented in a graphical form and the piston lateral motion and rotating motion are normalized to the piston stroke position, based on the reciprocating motion of a piston, as shown in Figure 13.

It is evident from the plot that the piston remains at the lower boundary cylinder liner for a longer time, as compared to the upper boundary of a cylinder wall. In addition, the piston is predicted to slide for a crank angle of $100^{\circ}$ before the TDC along the cylinder liner (Figure 13).

Figure 14 shows the measured vibratory response of the cylinder block in the vibration amplitudes, as captured by accelerometer. The vibration of the cylinder decays after the first impact of the piston on the upper boundary of a liner. The vibration is induced once 


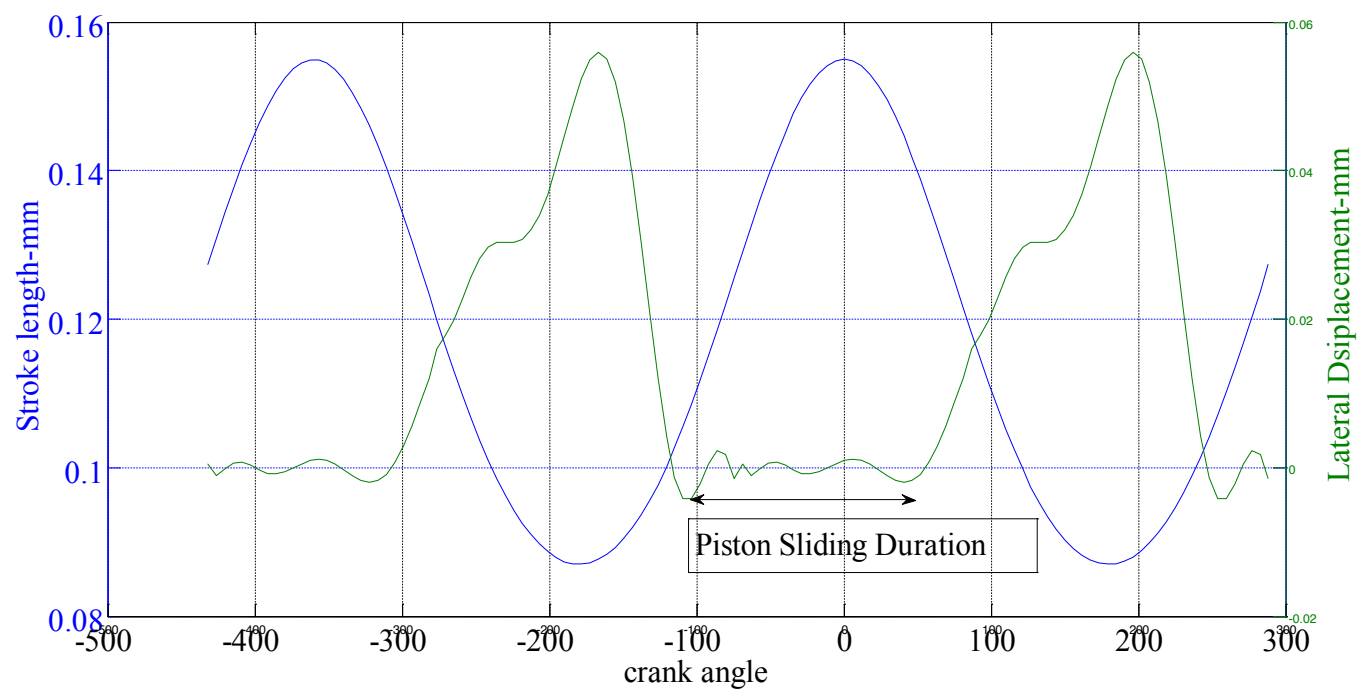

Figure13 The piston's secondary motion (Case 1)

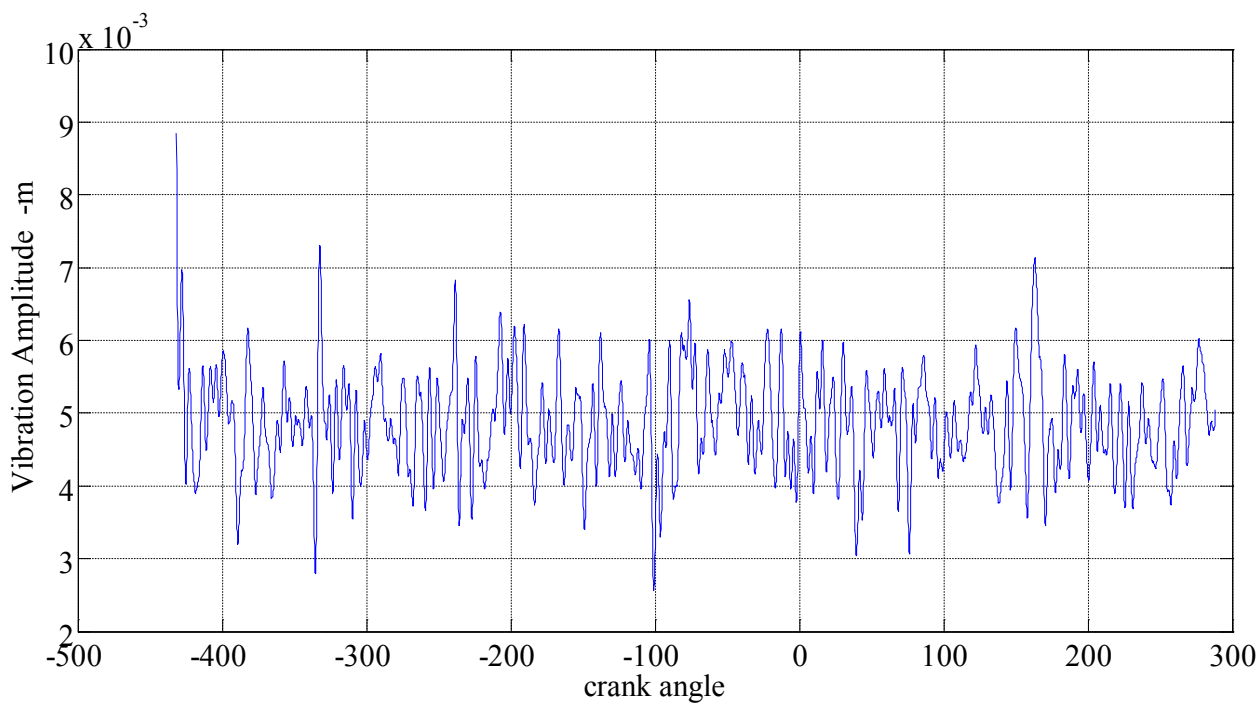

Figure14 Vibration response of the engine block (Case 1)

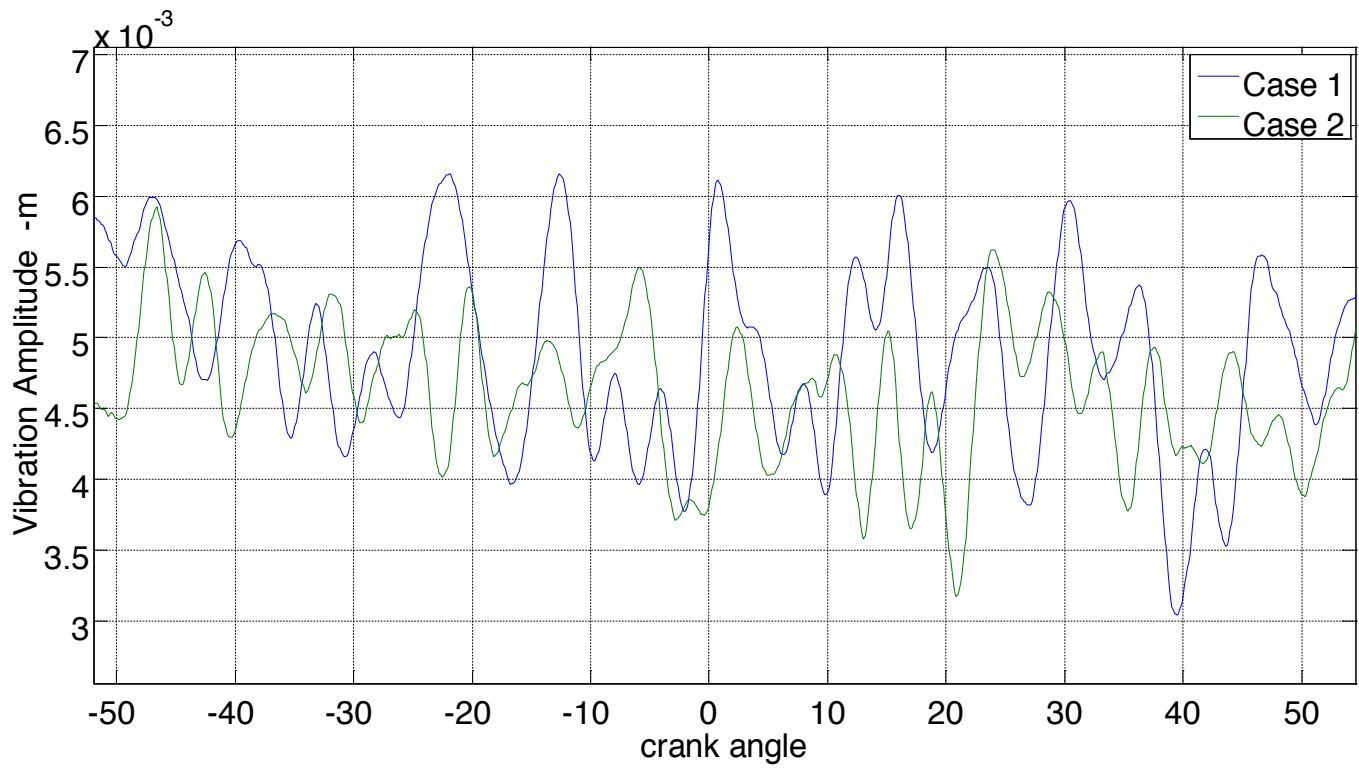

Figure 15 Effects of variations of the engine speed on engine block vibrations (2000 rpm) 


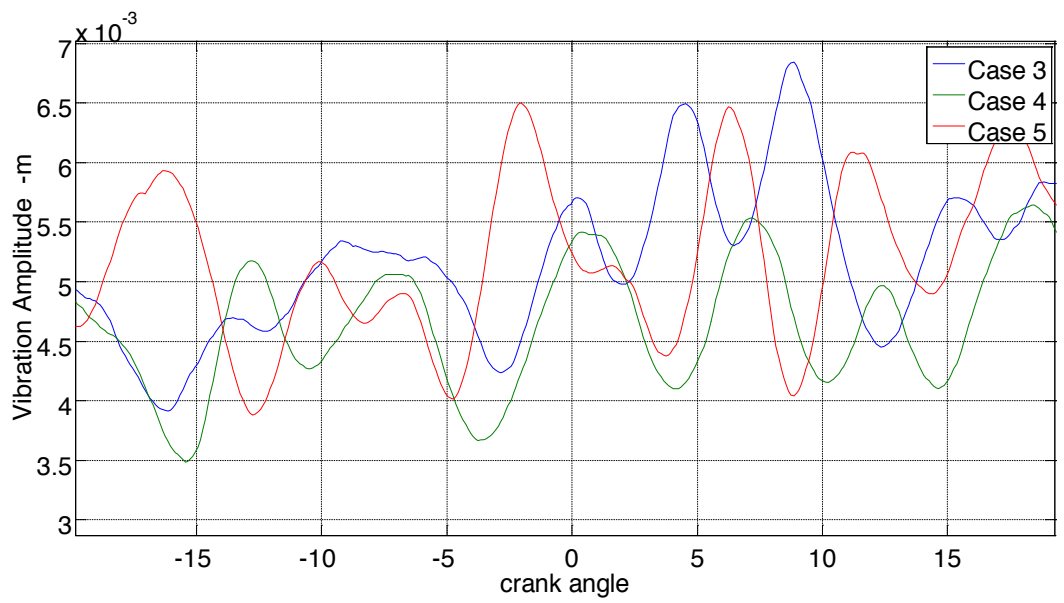

Figure 16 Effects of variations of the engine speed on block vibrations (3000 rpm)

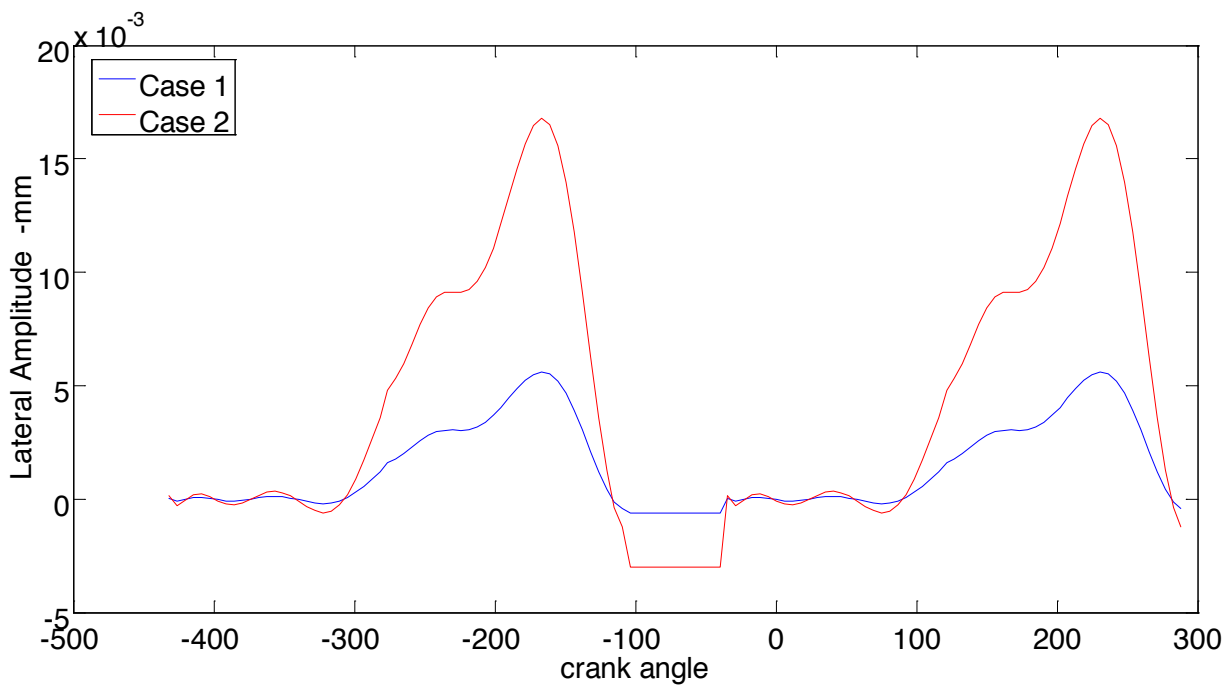

Figure 17 Effects of variations of the engine speed on the secondary motion of a skirt (2000 rpm)

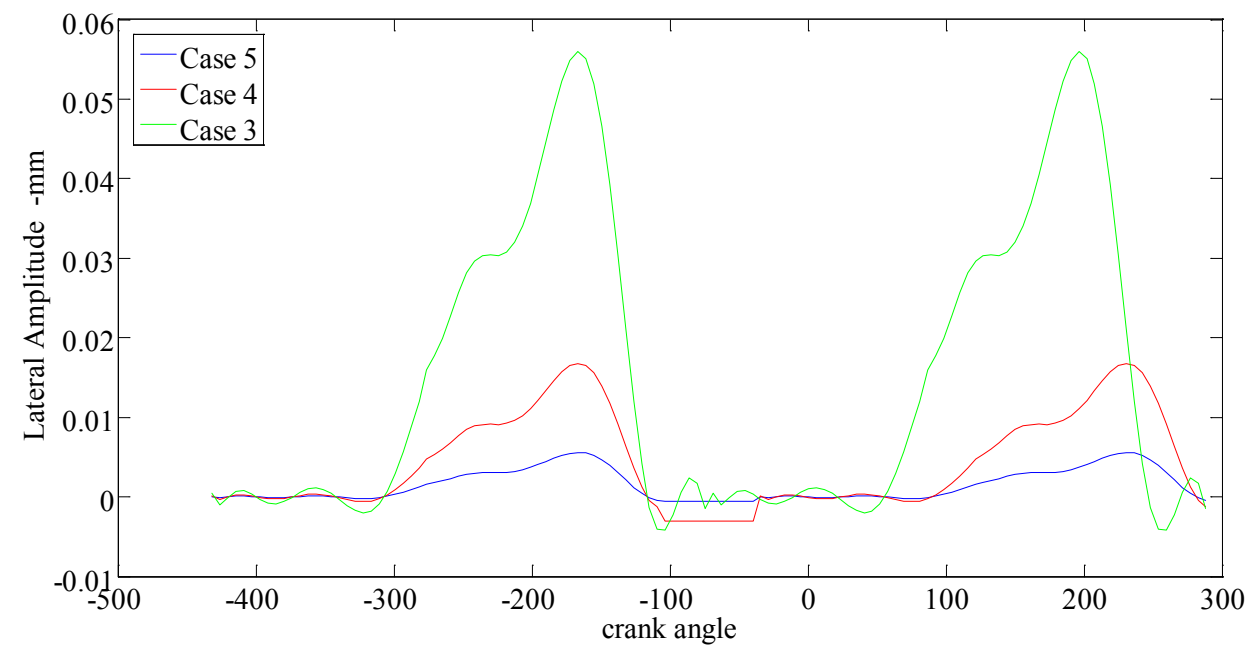

Figure 18 Effects of variations of the engine speed on the secondary motion of a skirt (3000 rpm)

again when the piston impacts lower cylinder liner. The induced vibrations had an amplitude of order of 7 $\times 10^{-3} \mathrm{~m}$. As the engine operating speed increases, the piston side thrust force, which is a function of the engine rotating speed, increases. An increase in the side thrust force, acting on the piston, results in the piston bouncing off the cylinder liner more frequently at higher speeds, as seen from Figures 15 and 16.

The induced vibrations of a block also increase with engine speed. The sliding duration also falls with 
an increase in velocity as shown in Figures 17 and 18 . This is due to the higher impact force and acceleration generated during the piston slap and the reaction impact force from a liner acting on the skirt increases. At the lower engine speeds, the vibration response of the cylinder block induced by the first slap of a piston has a longer duration to decay before the second slap occurs. However, with the speed increase, the vibration response of a block has the shorter duration of decay and response from the second slap is combined with the first one.

\section{Conclusions}

A lumped system model was discussed in the present paper. Various dynamic parameters of a system were calculated, using the concept of mobility, which were later used to simulate the lateral motion of a piston, as well as the resulting engine block vibrations.
Values of the first resonance frequencies of both the skirt and a liner were found to be in $100 \mathrm{~Hz}-160 \mathrm{~Hz}$ range and it remains unaffected by variations in the engine operational conditions. Several peaks were found in the simulated block vibrations, which were related to impacts of a skirt with liner. The COMSOL-7 software was then used to analyze the tilting motion of a piston, which showed a good match with that simulated by solving dynamic equations of motion. Effects of load and speed on lateral motion of piston skirt were also investigated. The piston skirt was also found to slide along a liner a few crank angle degrees before the TDC position. This sliding motion was less dominant during the power stroke as the bouncing motion dominates the dynamic motion of a skirt. The duration of sliding motion of a piston along the liner was observed to decrease with increase in load and speed conditions, which is in agreement with previous available literature.

\section{References}

[1] WANNATONG, K., CHANCHAONA, S., SANITJAI, S. Simulation algorithm for piston ring dynamics. Simulation Modelling Practice and Theory [online]. 2008, 16(1), p. 127-146. ISSN 1569-190X. Available from: https://doi.org/10.1016/j.simpat.2007.11.004

[2] FLORES, P., AMBROSIO, A., CLARO, J., LANKARANI, H. Translational joints with clearance in rigid multibody systems. Journal of Computational and Nonlinear Dynamics [online]. 2008, 3(1), 011007. ISSN 1555-1415, eISSN 1555-1423. Available from: https://doi.org/10.1115/1.2802113

[3] HAN, D.-CH., LEE, J.-S. Analysis of the piston ring lubrication with a new boundary condition. Tribology International [online]. 1998, 31, p. 753-760. ISSN 0301-679X. Available from: https://doi.org/10.1016/S0301679X(98)00096-6

[4] RAHNEJAT, H., BALAKRISHNAN, S., KING, P., HOWELL-SMITH, S. In-cylinder friction reduction using a surface finish optimization technique. Proceedings of the Institution of Mechanical Engineers, Part D: Journal of Automobile Engineering [online]. 2006, 220(9), p. 1309-1318. ISSN 0954-4070, eISSN 2041-2991. Available from: https://doi.org/10.1243/09544070JAUTO282

[5] CHO, S. H., AHN, S. T., KIM, Y. H. A simple model to estimate the impact force induced by piston slap. Journal of Sound and Vibration [online]. 2002, 255(2), p. 229-242. ISSN 0022-460X. Available from: https://doi.org/10.1006/ jsvi.2001.4152

[6] ZHANG, Z., XIE, Y., ZHANG, X., MENG, X. Analysis of piston secondary motion considering the variation in the system inertia. Proceedings of the Institution of Mechanical Engineers, Part D: Journal of Automobile Engineering [online]. 2009, 223(4), p. 549-563. ISSN 0954-4070, eISSN 2041-2991. Available from: https://doi.org/10.1243/09544070JAUTO1078

[7] FLORES, P., LEINE, R., GLOCKER, C. Modeling and analysis of planar rigid multibody systems with translational clearance joints based on the non-smooth dynamics approach. Multibody System Dynamics [online]. 2010, 23, p. 165-190. ISSN 1384-5640, eISSN 1573-272X. Available from: https://doi.org/10.1007/s11044-009-9178-y

[8] FARAHANCHI, F., SHAW, S. W. Chaotic and periodic dynamics of a slider-crank mechanism with slider clearance. Journal of Sound and Vibration [online]. 1994, 177(3), p. 307-324. ISSN 0022-460X. Available from: https://doi.org/10.1006/jsvi.1994.1436

[9] MCFADDEN, P., TURNBULL, S. Dynamic analysis of piston secondary motion in an internal combustion engine under non-lubricated and fully flooded lubricated conditions. Proceedings of the Institution of Mechanical Engineers, Part C: Journal of Mechanical Engineering Science [online]. 2011, 225(11), p. 2575-2585. ISSN 0954-4062, eISSN 2041-2983. Available from: https://doi.org/10.1177/0954406211408674

[10] GENG, Z., CHEN, J. Investigation into piston-slap-induced vibration for engine condition simulation and monitoring. Journal of Sound and Vibration [online]. 2005, 282(3-5), p. 735-751. ISSN 0022-460X. Available from: https://doi.org/10.1016/j.jsv.2004.03.057

[11] OFFNER, G., HERBST, H. M., PRIEBSCH, H. H. A methodology to simulate piston secondary movement under lubricated contact conditions. In: SAE 2001 World Congress: proceedings [online]. USA: SAE International, 2001. 
ISSN 0148-7191, eISSN 2688-3627, technical paper 2001-01-0565. Available from: https://doi.org/10.4271/200101-0565

[12] LIU, K., XIE, Y., GUI, C. A comprehensive study of the friction and dynamic motion of the piston assembly. Proceedings of the Institution of Mechanical Engineers, Part J: Journal of Engineering Tribology [online]. 1998, 212(3), p. 221-226. ISSN 1350-6501, eISSN 2041-305X. Available from:https://doi.org/10.1243/1350650981542038

[13] KIM, T. J. Numerical analysis of the piston secondary dynamics in reciprocating compressors. Journal of Mechanical Science and Technology. 2003, 17(3), p. 350-356. ISSN 1738-494X, eISSN 1976-3824.

[14] RUGGIERO, A., SENATORE, A. Computer model for the prediction of the impact force induced by piston slap in internal combustion engines, The Annals of the University Dunarea de Jos of Galati, Fascicle VIII: Tribology [online]. 2003, 2003, p. 129-134. ISSN 1221-4590.

[15] DESAI, H. Computer aided kinematic and dynamic analysis of a horizontal slider crank mechanism used for single-cylinder four stroke internal combustion engine. In: World Congress on Engineering WCE 2009: proceedings [online]. Vol. II. 2009. ISBN 978-988-18210-1-0, p. 1-3.

[16] WILSON, R., FAWCETT, J. N. Dynamics of the slider-crank mechanism with clearance in the sliding bearing. Mechanism and Machine Theory [online]. 1974, 9(1), p. 61-80. ISSN 0094-114X. Available from: https://doi.org/10.1016/0094-114X(74)90008-1

[17] HADDAD, S. D., TJAN, K. T. An analytical study of offset piston and crankshaft designs and the effect of oil film on piston slap excitation in a diesel engine. Mechanism and Machine Theory [online]. 1995, 30(2), p. 271-284. ISSN 0094-114X. Available from:https://doi.org/10.1016/0094-114X(94)00035-J

[18] KOIZUMI, T., TSUJIUCHI, N., OKAMURA, M., TSUKIJIMA, H., KUBOMOTO, I., ISHIDA, E. Reduction of piston slap excitation by optimizing piston profiles. In: SPIE 2002: proceedings [online]. 2002. p. 107-113.

[19] JANG, S., CHO, J. Effects of skirt profiles on the piston secondary movements by the lubrication behaviors. International Journal of Automotive Technology. 2004, 5(1), p. 23-31. ISSN 1229-9138, eISSN 1976-3832.

[20] NARAYAN, S. Effects of various parameters on piston secondary motion. In: 18th Asia Pacific Automotive Engineering Conference: proceedings [online]. USA: SAE International, 2015. ISSN 0148-7191, eISSN 2688-3627, technical paper 2015-01-0079. Available from: https://doi.org/10.4271/2015-01-0079.

[21] GUZZOMI, A., HESTERMAN, D., STONE, B. Variable inertia effects of an engine including piston friction and a crank or gudgeon pin offset. Proceedings of the Institution of Mechanical Engineers, Part D: Journal of Automobile Engineering [online]. 2008, 222(3), p. 397-414. ISSN 0954-4070, eISSN 2041-2991. Available from: https://doi.org/10.1243/09544070JAUTO590

[22] GUZZOMI, A., HESTERMAN, D., STONE, B. The effect of piston friction on engine block dynamics. Proceedings of the Institution of Mechanical Engineers, Part K: Journal of Multi-body Dynamics [online]. 2007, 221(2), p. 277-289. ISSN 1464-4193, eISSN 2041-3068. Available from: https://doi.org/10.1243/14644193JMBD66

[23] GERGES, S. N. Y., DE LUCA, J. C., LALOR, N. The influence of cylinder lubrication on piston slap. Journal of Sound and Vibration [online]. 2002, 257(3), p. 527-557. ISSN 0022-460X. Available from: https://doi.org/10.1006/ jsvi.2002.5051

[24] TAN, Y. C., RIPIN, Z. Technique of measuring piston secondary motion using laser displacement sensors. Experimental Mechanics [online]. 2012, 52, p. 1447-1459. ISSN 0014-4851. Available from: https://doi.org/10.1007/ s11340-012-9600-x

[25] COMFORT, A. An introduction to heavy-duty diesel engine frictional losses and lubricant properties affecting fuel economy - Part I. SAE International [online]. 2003, 2003-01-3225. ISSN 0148-7191, eISSN 2688-3627. Available from:https://doi.org/10.4271/2003-01-3225

[26] TAYLOR, R., COY, R. Improved fuel efficiency by lubricant design: A review. Proceedings of the Institution of Mechanical Engineers: Part J: Journal of Engineering Tribology [online]. 2000, 214(1), p. 1-15. ISSN 1350-6501, eISSN 2041-305X. Available from: https://doi.org/10.1177/135065010021400101

[27] ZWEIRI, Y., WHIDBORNE, J., SENEVIRATNE, L. Instantaneous friction components model for transient engine operation. Proceedings of the Institution of Mechanical Engineers: Part D: Journal of Automobile Engineering [online]. 2002, 214, p. 809-824. ISSN 0954-4070, eISSN 2041-2991. Available from: https://doi.org/10.1243/0954407001527664

[28] TAN, Y. C., RIPIN, Z. M. Frictional behavior of piston rings of small utility two-stroke engine under secondary motion of piston. Tribology International [online]. 2011, 44(5), p. 592-602. ISSN 0301-679X. Available from: https://doi.org/10.1016/j.triboint.2010.12.009

[29] SHI, X., POLYCARPOU, A. A. Measurement and modeling of normal contact stiffness and contact damping at the meso scale. Journal of Vibration and Acoustics [online]. 2005, 127(1), p. 52-60. ISSN 1048-9002, eISSN 1528-8927. Available from: https://doi.org/10.1115/1.1857920

[30] CAWLEY, P., CLAYTON, D. A vibration technique for the measurement of contact stiffness. Mechanical Systems and Signal Processing [online]. 1987, 1(3), p. 273-283. ISSN 0888-3270. Available from: https://doi. org/10.1016/0888-3270(87)90104-X 
[31] HIXSON, E. L. Mechanical impedance. In: Harris' shock and vibration handbook. HARRS, C. M., PIERSOL, A. G. (eds). New York: McGraw-Hill, 1988. ISBN 0-07-137081-1.

[32] HYNNA, P. Mechanical mobility technique [online]. Research report no. BVAL37-021228. Espoo: VTT Technical Research Centre of Finland, 2002. Available from: http://www.vtt.fi/inf/julkaisut/muut/2002/BVAL37-021228.pdf

[33] MITTLER, R., MIERBACH, A., RICHARDSON, D. Understanding the fundamentals of piston ring axial motion and twist and the effects on blow-by. In: ASME 2009 Internal Combustion Engine Division Spring Technical Conference: proceedings [online]. 2009, ICES2009:76080. ISBN 978-0-7918-4340-6, p. 721-735. Available from: https://doi.org/10.1115/ICES2009-76080

[34] TAKIGUCHI, M., ANDO, H., TAKIMOTO, T., URATSUKA, A. Characteristics of friction and lubrication of two-ring piston. JSAE Review [online]. 1996, 17(1), p. 11-16. ISSN 0389-4304. Available from: https://doi.org/10.1016/0389-4304(95)00050-X

[35] XIAO, S., YAN, F., LU, CH., LU, Z. Optimization design of piston structure for abnormal noise control in a singlecylinder gasoline engine. Advances in Mechanical Engineering [online]. 2018, 10, p. 1-16. ISSN 1687-8140, eISSN 1687-8140. Available from: https://doi.org/10.1177/1687814018769407

[36] NARAYAN, S., GUPTA, V. Numerical analysis of secondary motion of piston skirt in engines. International Journal of Acoustics and Vibrations. 2018, 23(4), p. 557-565. ISSN 1027-5851, eISSN 2415-1408.

[37] NARAYAN, S. Analysis of piston slap motion. International Journal of Applied Mechanics and Engineering [online]. 2015, 20(2), p. 445-450. eISSN 2353-9003. Available from: https://doi.org/10.1515/ijame-2015-0030

[38] NARAYAN, S. Piston slap noise in engines. International Journal of Applied Engineering Research. 2015, 8(14), p. 1695-1700. ISSN 0973-4562, eISSN 0973-9769.

[39] MAHROOGI, F., NARAYAN, S. Dynamic-analysis-of-piston-secondary-motion-using FEM method. In: 26th International Congress on Sound and Vibration: proceedings. 2019. ISSN 2329-3675, ISBN 978-1-9991810-0-0.

[40] KAISAN, M. U., YUSUF, L. O., IBRAHIM, I. U., ABUBAKAR, S., NARAYAN, S. Effects of propanol and camphor blends on emissions and performance of a spark ignition engine. American Chemical Society (ACS) Omega [online]. 2020, 5(41), p. 26454-26462. ISSN 2470-1343. Available from: https://doi.org/10.1021/acsomega.0c02953

[41] GRUJIC, I., STOJANOVIC, N., PESIC, R., DAVINIC, A., NARAYAN, S. Numerical analysis of IC engine operation with high pressure hydrogen injections. Transactions of FAMENA [online]. 2020, 44(1), p. 55-56. ISSN 1333-1124, ISSN 1849-1391. Available from: https://doi.org/10.21278/TOF.44105

[42] MAHROOGI, F. O., NARAYAN, S. A recent review of hybrid automotive systems in GCC region. Proceedings of Institute of Mechanical Engineers Part D: Journal of Automotive Engineering [online]. 2019, 233(14), p. 13931402. ISSN 0954-4070, eISSN 2041-2991. Available from: https://doi.org/10.1177/0954407019836055

[43] ABUBAKAR, S., ANAFI, F. O., KAISAN, M. U., NARAYAN, S., UMAR, S., UMAR, U. A. Comparative analysis of experimental and simulated performance of a mixed mode solar dryer. Proceedings of Institute of Mechanical Engineers Part C: Journal of Mechanical Engineering [online]. 2019, 234(7), p. ISSN 0954-4062, eISSN 20412983. Available from: https://doi.org/10.1177/0954406219893394

[44]KAISAN, M. U., ABUBAKAR, S., ASHOK, B., BALASUBRAMANIAN, D., NARAYAN, S., GRUJIC, I., STOJANOVIC, N. Comparative analyses of biodiesel produced from Jatropha and neem seed oil using a gas chromatography mass spectroscopy technique. Biofuels [online]. 2018, lates articles. ISSN 1759-7269, eISSN 1759-7277. Available from: https://doi.org/10.1080/17597269.2018.1537206

[45] NARAYAN, S. A review of diesel engine acoustics. FME Transactions [online]. 2014, 42(2), p. $150-154$. ISSN 1451-2092, eISSN 2406-128X. Available from: https://doi.org/10.5937/fmet1402150N

[46] NARAYAN, S., MILOJEVIC, S., GUPTA, V. Combustion monitoring in engines using accelerometer signals. Journal of Vibroengineering [online]. 2019, 21(6), p. 1552-1563. ISSN 1392-8716, eISSN 2538-8460. Available from: https://doi.org/10.21595/jve.2019.20516

[47] MAHROOGI, F. O., NARAYAN, S., GUPTA, V. Acoustic transfer function in gasoline engines. International Journal of Vehicle Noise and Vibration (IJVNV) [online]. 2018, 13(3), p. 270-280. ISSN 1479-1471, eISSN 1479-148X. Available from: https://doi.org/10.1504/IJVNV.2018.097212

[48] NARAYAN, S. Wavelet analysis of diesel engine noise. Journal of Engineering and Applied Sciences [online]. 2013, 8(8), p. 255-259.ISSN 1816-949x, eISSN 1818-7803. Available from: https://doi.org/10.36478/jeasci.2013.255.259

[49] NARAYAN, S. Effect of dwell time on noise radiated from diesel engine. International Journal of Applied Engineering Research. 2013, 8(11), p. 1339-1347. ISSN 0973-4562, eISSN 0973-9769.

[50] MUHAMMED, M. M., KAISAN, M. U., ABUBAKAR, S., NARAYAN, S. Determination of wear metals debris concentration in aircraft engines. International Journal of Innovative Technology and Exploring and Engineering (IJITEE). 2019, 8(11), p. 1289-1292 eISSN 2278-3075.

[51] NARAYAN, S., ALSAGRI, A. S., GUPTA, V. Design and analysis of hybrid automotive suspension system. International Journal of Mechanical and Production Engineering Research and Development (IJMPERD) [online]. 2019, 9(4), p. 637-642. ISSN 2249-6890, eISSN 2249-8001. Available from: https://doi.org/10.24247/ ijmperdaug201963 
[52] MAHROOGI, F. O., NARAYAN, S. Design and analysis of double wishbone suspension systems for automotive applications. International Journal of Mechanical and Production Engineering Research and Development (IJMPERD) [online]. 2019, 9(4), p. 1433-1442. ISSN 2249-6890, eISSN 2249-8001. Available from: https://doi. org/10.24247/ijmperdaug2019148

[53] STOJANOVIC, N., GLISOVIC, J., GRUJIC, I., NARAYAN, S. Influence of size of ventilated brake disc ribs on air flow velocity. International Journal of Advanced Science and Technology(IJAST) [online]. 2020, 29(1), p. 637-647. ISSN 2005-4238, eISSN 2207-6360. Available from: http://sersc.org/journals/index.php/IJAST/article/view/3285

[54] MAHROOGI, F. O., NARAYAN, S. Effects of dampers on piston slapping motion. International Journal of Vehicle Noise and Vibration (IJVNV) [online]. 2020, 16(1/2), p. 46-57. ISSN 1479-1471, eISSN 1479-148X. Available from: https://doi.org/10.1504/IJVNV.2020.112432

[55] NARAYAN, S., GUPTA, V. Frequency characteristics of in cylinder pressure of a gasoline engine. Journal of Applied Engineering Science [online]. 2021, 19(1), p. 92-97. ISSN 1451-4117, eISSN 1821-3197. Available from: https://doi.org/10.5937/jaes0-27156

[56] NARAYAN, S. Modelling of noise radiated from engines. In: The 11th International Conference on Automotive Engineering: proceedings [online]. 2015. 2015-01-0107. ISSN0148-7191, eISSN 2688-3627. Available from: https://doi.org/10.4271/2015-01-0107

[57] NARAYAN, S. Analysis of noise emitted from diesel engines. Journal of Physics: Conference Series [online]. 2015, 662, 012018. ISSN 1742-6588, eISSN 1742-6596. Available from: https://doi.org/10.1088/1742-6596/662/1/012018 